\title{
MEASUREMENT OF INTELLECTUAL CAPITAL: THEORETICAL AND EMPIRICAL FRAMEWORK
}

\author{
Biserka Komnenić \\ Novi Sad School of Business, Novi Sad, Republic of Serbia \\ Jovan Njegić \\ Novi Sad School of Business, Novi Sad, Republic of Serbia
}

\begin{abstract}
The concept of intellectual capital (IC) intends to identify and to define firms intangible strategic assets, to classify them and measure their contribution to the firm's process of value creation. Measurement of the IC enables the firm to obtain the information about the contribution of all strategic assets in the process of value creation, which significantly enhance the firm's decision-making process because the decisions can be based on the comprehensive and relevant information. The IC measurement is a complex process for its static and dynamic dimension of its elements. This paper aims to shed some light into this complex field, by synthesising and explaining all relevant aspects of research concerning measurement of the IC. The methodology used is a systematic literature review aiming to identify, appraise, select and synthesise high-quality research evidence and arguments relevant to the IC measurement, which includes theoretical and empirical contributions to this topic. The paper analyses research relevant to five main areas: firm motives for IC measurement; advantages of IC measurement; specificity and complexity of IC measurement; issues concerning IC indicators; most common approaches to the IC measurement and its methodologies. Since this paper in systematical and logical manner present all relevant aspects of research regarding the topic of IC measurement it generates, from very fragmented sources, an theoretical and empirical framework for this field of research. In that way, the paper contributes to the existing literature on these topics, it provides insight into the current state in the field of IC measurement and facilitates future research in this area.
\end{abstract}

Keywords: Intellectual capital, Measurement, Complexity, Methods, Indicators, Motives, Reporting, Value creation

JEL classification: $\mathrm{O} 34$ 


\title{
MERENJE INTELEKTUALNOG KAPITALA: TEORIJSKI I EMPIRIJSKI OKVIR
}

\begin{abstract}
Sažetak: Koncept intelektualnog kapitala (IK) usmeren je na identifikovanje i definisanje strateških neopipljivih sredstava organizacija, njihovog klasifikovanja i merenja njihovog doprinosa u procesu stvaranja vrednosti. Merenje intelektualnog kapitala omogućava preduzeću da dobije informacije o doprinosu svih strateških sredstava stvaranju vrednosti, što u značajnoj meri unapređuje proces donošenja odluka s obzirom da se odluke donose na osnovu sveobuhvatnih informacija. Samo merenje intelektualnog kapitala je složen proces, pre svega zbog istovremeno statičke $i$ dinamičke prirode neopipljivih resursa koji ga čine.Namera ovog rada je da na jedan sveobuhvatan način pokuša da dodatno pojasni ovu veoma složenu oblast u okviru koncepta intelektualnog kapitala, čineći to pre svega sintetizovanjem i pojašnjavanjem svih relevantnih aspekata kojima se bavi oblast merenja IK. U istraživanju je primenjena metodologija sistematskog pregleda literature, s ciljem da se identifikuju, procene, selektuju i sintetizuju relevantna teorijska i empirijska istraživanja koja su dala doprinos $u$ oblasti merenja intelektualnog kapitala. Rad analizira istraživanja vezana za sledećih pet glavnih aspekata: motivi merenja IK, koristi od merenja $I K$, specifičnost $i$ složenost merenja IK, problematika indikatora merenja IK, najšire zastupljeni pristupi merenju IK i metode merenja IK. S obzirom da ovaj rad sistematizuje inače veoma fragmentisana teorijska i empirijska istraživanja u oblasti merenja IK $i$ sve relevantne aspekte koje ova oblast pokriva, on kao takav kreira celinu teorijskog $i$ empirijskog okvira oblasti merenja IK $i$ na taj način doprinosi postojećoj naučnoj literaturi koja se bavi ovom problematikom. Takođe, sistematizovanje i pojašnjenje svih relevantnih aspekata istraživanja u oblasti merenja IK daje sliku trenutnog stanja u ovoj oblasti $i$ olakšava buduća, posebno početnička istraživanja, ove oblasti u okviru koncepta intelektualnog kapitala.
\end{abstract}

Ključne reči: intelektualni kapital, merenje, motivi, kompleksnost, indikatori, metode, izveštavanje, stvaranje vrednosti

\section{INTRODUCTION}

Those who are for the first time to engage in the study of the concept of Intellectual Capital (IC) may have the impression that this area is chaotic, complex and vague because the critical research of all the essential aspects of this concept (IC term and its components definition, its management, measurement and reporting) are fragmented or not systematised. Also, since the concept of IC is an object of interest of different disciplines, its study is approached from different perspectives, that is, from the perspective of economics; strategic management; finance; accounting; human resources; marketing and communication, psychology. Therefore, the scientific challenge in the exploration of the concept of intellectual capital lies in the fact that in 

FRAMEWORK

order to shape its scientific framework, it is necessary to link all the relevant theoretical components that make up the building blocks of the emergence of this concept, as well as all the highly fragmented aspects of its study which today form the general framework for the exploration of the IC concept. The concept of IC is now at a stage where its further development no longer depends on the development of new frameworks of IC components, its classifications and new definitions, but on framing all relevant aspects of its research into a single theoretical unit. Also, empirical testing of this concept and its validation in practice is of crucial importance for its further development as a scientific discipline, where the IC measurement plays a crucial role.The subject of this paper is the field of IC measurement. Its purpose is to primarily synthesise fragmented relevant research, on all essential aspects concerning IC measurement, and in one comprehensive, consistent and logical manner provides insight into the current state of the research concerning this topics. Through a systematic literature review, research on some of the most significant existing literature on critical issues concerning intellectual capital measurement and its developed path has been conducted. For this research, only papers and books that, according to the author's view has the most extensive influence on IC measurement development have been selected and discussed. The emphasis is on significant theoretical and empirical contributions relating to this field of research. This paper analysed research relevant to five main areas: firm motives for IC measurement; advantages of IC measurement; specificity and complexity of IC measurement; issues concerning IC indicators; most common approaches to the IC measurement and methodologies for IC measurement.

\section{METHODOLOGY}

In order to fully map the prior research in the field of IC measurement, a systematic literature review was conducted. That includes the use of the replicable, scientific and transparent process, which minimises bias through extensive literature searches of published studies. In order to assess the relevance and size of the literature and to state clearly the focus of the research study, the scope of the literature review process was defined by factors of IC measurement disciplinary perspectives, keywords and the quality of the research sources. The papers were studied and classified regarding IC measurement research interest. The results of the selection formed the sub-headings of the sections of this paper. The seventy eight scientific and expert papers and books were chosen as most relevant regarding the all relevant aspects of IC measurement. Since today there is no academic work which synthesises in one place all relevant issues concerning IC measurement, this paper strives to provide comprehensive and consolidated insight concerning this field of research. Only the most relevant researches were considered to be used to create 
Biserka Komnenić, Jovan Njegić | 133

such a comprehensive picture. Therefore this paper contributes to all future research, providing one logical and systematic insight in the current state of the development of IC measurement.

\section{THE MEASUREMENT OF IC - THEORETICAL AND EMPIRICAL CONTRIBUTIONS}

The defining IC, its components and its taxonomy, its management and measurement represents main aspects of the research regarding the concept of Intellectual Capital. This multifaceted perspective on the firm's key capabilities indicates that its main object of research is focused on the process of value creation itself, the possible ways of articulating this process and directing it towards the firm strategic goals. The research into the IC concept is generally directed in two ways. One relates to the construction of the conceptual framework and the IC management strategy, while the other deals with the design of management tools, especially in the domain of intangible assets performance measurement systems. This second line of research, which is the subject of this paper, is aimed at developing management information systems, that is, balanced performance measurement systems that would be able to measure, in addition to classical financial performance, firms non-financial performance based on its intangibles.

Aldo, most prominent authors in IC discipline, have contributed in the development of IC concept in many ways, the following one gave the most significant contributions to the research of the IC measurement: Kaplan and Norton (1992); Sveiby (1997), Edvinsson and Malone (1997), Pulic (2002), Roos and Roos (1997), Johanson, Martensson and Skoog (1999), Lev (2001), Andriessen, Frijlink, van Gisbergen and Blom (1999) and Achten (1999). Besides, there were institutional project initiatives regarding the development of IC measurement framework and attempts for its standardisation like DTID council from 1997, MERITUM project 2001, Work-life 2000, OECD 1999, FASB from 2001 and others.

One of the crucial contributions to the empirical research was given by companies that were assembled within the Intellectual Capital Management (ICM) gathering club. The principal creators of the term ICM and initiators of founding ICM Gathering are Leif Edvinsson (Sweden), Gordon Petrash (USA), Hubert St. Onge (Canada) and Patrick Sullivan (USA). The first company which adopted a full ICM approach was Skandia (a Swedish Insurance company) in the 1990s under the leadership of Leif Edvinsson. The first firms'pioneers (seven companies that include Dow Chemical, DuPont, HewlettPackard, Hughes Space and Communication, Hoffman LaRoche and Skandia) got together in January 1995 to exchange notes and formed the first ICM 
134 | MEASUREMENT OF INTELLECTUAL CAPITAL: THEORETICAL AND EMPIRICAL FRAMEWORK

Gathering in Berkeley, California, USA. Those companies, encouraged by academics pioneers in exploring the IC concept such as Lief Edvinson, Patrick Sullivan, Gordon Petrash, Hubert St. Onge, started to apply intellectual capital management in practice. In that way, they allowed academics and experts to observe these phenomena and conduct empirical research on the management and measurement of IC. Those researches resulted with crucial conclusions and hypothesis regarding all relevant aspects of the concept of IC such as definition of the term Intellectual Capital, its classification, insight in the possible ways of extracting value from IC, standardisation of the content and meaning of the components of IC, identification of steps in the process of the development of the IC management system, purpose and ways for IC measurement, and reasons for its external and internal reporting.

To date, a considerable number of empirical research has been conducted. The subjects of these research so far are varied: from the importance of the reporting on IC and creation of those reports; research on the stakeholder perception on value of IC, research on the nature of IC measurement indicators, research of the characteristics of IC resources and their interactions, research on the purpose, wayes, content and outcome of the IC measurement, to the investigation of the impact of IC on the firms financial performance and evaluation of the future benefits derived from IC. Empirical researches used a variety of methodologies, from interviews and questionnaires, case studies, to econometric and statistical methods. The following authors gave a contribution to:

- Research on the process of IC measurement itself: Achten (1999), Hoogendoorn, de Bos, Krens, Veerman and Beek (1999), Marr and Chatzkel (2004).

- Purpose, motives and importance of IC measurement and reporting: DATI (1998), Johanson et al. (1999), Andriessen et al. (1999), Miller et al. (1999), Guthrie (1999), Brennan (1999), Botosan (1997), Bukh, Larsen, Gormsen and Mouritsen (2002), Marr, Gray and Neely (2003), Martson and Robson (1997);

- Perception of the stakeholders about the reporting on the value of the IC: Bornemann, Knapp, Schneider and Sixl (1999), Edvinsson and Richtner (1999), Kooistra and Zijlstra (2001), Pablos (2002), Starovic and Marr (2003).

- Correlation between organisational characteristics and reporting on the IC: Taylor (1999), Beaulieu, Williams and Wright (2002), Ahmed and Courtis (1999).

- Characteristics of the IC resources, their interactions and the nature of indicators for IC measurement: Bornemann et al. (1999), Canibano, 
Garcia-Ayuso, Sanchez, Chaminade, Olea and Escobar (1999), Johanson (1999), Bontis (2000), Roos and Roos (1997), Marr and Schiuma (2001).

- Exploring content and outcomes of IC measurement, and its impact on the firm financial performance: Pulic (2000), Kujansivu and Lonquist (2005), Chen, Cheng and Hwang (2005), Abdolmohammadi (2005), Shiu (2006a, 2006b), Chan (2009), Marr, Neely and Thomas (2002).

The research results revealed that IC measurement is considered to be very important for firm long-term success. The results of empirical research on impact of IC resources on corporate performance confirmed positive relationship between IC and firms business performance (Pulic (2000), Firer, and Williams (2003), Chen et al. (2005), Abdolmohammadi (2005), Shiu (2006a), Kujansivu and Lonqvist (2007), Kamath (2008), Chan (2009), Chu, Chan and Wu (2011), Komnenic and Pokrajcic (2011, 2013). Furthermore, empirical researches confirmed that the firms which applied a systematic approach to the management of IC are more successful compared to others (DTID (1997), DATI (1999), Bornemann et al. (1999), Johanson (1999). Also, the researches have contributed to the identification of a large number of different IC indicators (DTID Concil, (1997), Miller et al., (1999), MERITUM, DATI, 2001). Furthermore, results of researches regarding the stakeholder's perception on the IC reporting revealed firms internal and external reasons for such activities, the stakeholders' perceptions of the advantages and disadvantages of external reporting on IC as well as the methods most used to prepare external IC reports. The authors who mostly contributed to this topics are Bornemann et al. (1999), Edvinsson and Richtner (1999), Kooistra and Zijlstra (2001).

The overall outcome of those researches was a large number of hypotheses and further development and improvement of the number of IC measurement methodologies aiming for better understanding of IC influence on the firm process of value creation and firm business performance.

\section{REASONS FOR MEASURING INTELLECTUAL CAPITAL}

The concept of intellectual capital is focused on defining organisation intangible strategic assets, their classification as well as on the development of indicators for monitoring their contribution to the value creation. In this context, the development of IC measurement methods provides systematic information on the contribution of all key strategic resources to the firm's process of value creation. For the purpose of this paper, according to authors opinion, the following, most accepted theoretical explorations on the motives for IC measurement are presented. 
136 | MEASUREMENT OF INTELLECTUAL CAPITAL: THEORETICAL AND EMPIRICAL FRAMEWORK

Sveiby (1997) highlights that the first question for anyone embarking on an IC measurement initiative must be: What is the purpose of our measuring initiative? Sveiby (1997) identifies three motives for IC measurement: management control, PR purpose and Learning motive, according to him, the only one with meaningful purpose. He strongly underlines that firms should be cautious if their reason for IC measurement is to improve internal performance or in other words management control. According to him, this motive carries a significant risk for the firm regarding possible abuse from management side since the managers are always in pursuit of reporting great performance results. Since even physical resources can be the subject of accounting manipulations, he is asking one to imagine what level of risk in terms of abuse intangibles measurement system is open to. He emphasises that measurement of intangibles is not legally regulated, there is no standard for it, it is voluntary and consequently do not include any penalty for manipulation. Regarding the PR motive, Sveiby also recommends great caution, given that the need for public reporting on the value of firm's intangibles also can lead to manipulation of shareholders and other firm's stakeholders, especially in the context of the perception of firm market value. The learning motive is according to Sveiby, the only reasonable motive for IC measurement. It enables the firm to enhance its ability to create added value, and that through the articulation of the process of value creation identify its gaps and its opportunities (cut the costs, explore opportunities for value creation).

Andriessen (2004) stated that two general groups of motives for IC measurement could be extracted: those relating to the need to improve the quality of firms' management, and those related to improving communication with stakeholders.

Marr, Gray and Neely (2003) in their paper "Why do firms measure their intellectual capital?" suggests five main motives for firms to measure their IC. The opinion of the authors of this paper is that their proposition provides the most comprehensive framework regarding these topics. These motives are the following: Strategy formulation, Strategy assessment and execution, Strategic development, diversification and expansion, Compensation and Communication to external stakeholders. Relying on the research mentioned above (mostly on Marr et al., 2003) and other relevant ones concerning the discussion on the motives for IC measurement, the following motives for IC measurement are briefly presented.

\subsection{IMPROVING THE QUALITY OF THE FIRM'S MANAGEMENT}

In the IC literature exploring the IC measurement issues, it is often emphasised that "what can be measured can be managed". Stewart (1999), stresses that this phrase represents one of the oldest clichés in management. He points out that 
firms have always managed people, work ethics, business strategy, which are virtually immeasurable categories, and in business, everything, including people, work ethics and strategy, ultimately appears in the income statement.

Sveiby. (1997), Edvinsson (1997) and Ross (1997,) gave another, more valid reason for measuring IC which point to the increasing importance of intangible resources in the firm's process of value creation and competitive advantage. According to them, IC measurement methods help firms to identify the strategic resources that constitute their IC, recognise their importance, and understand that intellectual capital management requires different management methods compared to those used for management of material and financial resources. That has fostered research on the possibility of measuring of IC and resulted in the formulation of new tools that help managers to manage knowledge-based businesses more successfully.

Also, Kaplan and Norton (1996), through their Balanced Scorecard measurement system try to complement the firm's financial performance measures with operational measures, thus providing a balanced view of the results of the activities undertaken and insight into the key factors of value creation - critical strategic resources that determine the future success of the firm. As the strategic resources of today's firms are mostly intangible, the need to value intellectual capital is linked to the process of formulating a resource-based strategy. Another goal of a balanced performance view is to provide managers with feedback on the effects of their activities, which should help them, evaluate firm strategy and implement it. Over time companies started to use Kaplan and Norton (1992) "Balanced Scorecard" to translate a long-term strategy into short-term goals and activities, where need to improve internal management shifts from the sphere of performance measurement to the sphere of strategy implementation.

\subsection{MEASUREMENT OF IC TO FORMULATE A FIRM STRATEGY}

The goal of IC measurement is to enable the practical implementation of a vision-based and value-creating strategy through the establishment of the strategy through the organisational resources themselves. For the firm whose primary sources of competitive advantage are intangibles, strategy formulation should be based on the identification and definition of its core competencies. In this way - through the strategy itself, the firm emphasises that organisational competencies are its underlying potential for generating future revenues. The IC measurement should help the firm to identify, monitor and develop its specific competencies, knowledge and skills. Different firms focus on the development of different competencies, and it is this diversity that differentiates them and makes them recognisable in a competitive environment. Grant (1991), believes that in formulating a corporate strategy, the intellectual capital of the firm represents a 
138 | MEASUREMENT OF INTELLECTUAL CAPITAL: THEORETICAL AND EMPIRICAL FRAMEWORK

critical issue and its primary source of profitability. Therefore, gaining competitive advantage and improving business performance is directly dependent on the strategic identification and development of IC.

\subsection{MEASUREMENT OF IC IN ORDER TO EVALUATE AND IMPLEMENT THE STRATEGY}

Developing IC indicators help assess the progress of strategy implementation. This reason for measuring IC is cited by authors such as Marr et al. (2003), Kaplan and Norton (1996), Edvinsson and Malone (1997), Bukh, Larsen, Gormsen and Mouritsen (2001). According to Marr et al. (2003), information about IC is of little importance if it is not related to the firm strategy, since confirmation or rejection of strategic assumptions significantly affects the allocation of organisational resources. Neely, Mills and Gregory (1996), pointed out that any performance measurement system should be used to evaluate and review assumptions that underpin the ongoing strategic direction. Marr et al. (2003), stated that many performance measurement systems assume causal relationships or are based on business hypotheses that allow an organisation to test the challenges of each supporting hypothesis. He refers to Kaplan and Norton (1996), who showed many examples of causal systems in the form of strategic maps. They stress that in order to execute a strategy successfully, continuous performance measurement is required.

Evidence of a correlation between IC indicators and firm performance is provided in the Ittner and Larcker (1998), study. The authors found evidence that customer satisfaction measures are leading indicators of consumer behaviour (customer retention, revenue and revenue growth), customer growth and accounting results (business unit revenue, profit margins, sales revenue). Their findings are supported by empirical evidence gathered by Helmi (1998), Yeung and Ennew (2001). By using a range of different financial measures, they provided evidence of a positive impact of customer satisfaction on the firm's business performance. Rucci et al (1998), has also developed a business model for "Sears" that monitors business performance improvements through management behaviours, employee attitudes, customer satisfaction and financial results. Also, by studying "Shell International", Marr et al. (2003), confirmed the positive impact of intangible assets on employee satisfaction, organisational culture, organisation environmental and social responsibility, and its financial results.

The results of all these studies indicate that IC measurement provides managers with valuable information based on which they can evaluate the success of the current strategy and its implementation. It enables the firm to monitor the state and development of its intangible resources continuously, and allow management to react promptly and take the necessary corrective actions in order to execute the planned 
Biserka Komnenić, Jovan Njegić | 139 strategy. Measurement of IC should enable management to evaluate the path leading to the achievement of strategic goals and to provide information on the effects of implemented strategic activities.

\subsection{STRATEGIC DEVELOPMENT, DIVERSIFICATION AND EXPANSION}

Measuring IC should also contribute to the firm strategic positioning, diversification and expansion (Marr et al. 2003). In business practice, especially since the 1980s, there have been a large number of acquisitions made by those firms that wanted to obtain critical resources. There are other external ways of obtaining IC resources, for example, through the establishment of strategic alliances, joint ventures or the purchase of patents or licenses. Lev (2001), stresses that the synergy associated with $\mathrm{R} \& \mathrm{D}$ and other intangible resources is one of the main motives for engaging in acquisitions of other firms or strategic partnerships. Typically, the price paid for a firm that is the target of a takeover (especially those firms operating in the services and high technology sectors) is several times its book value, which is due to the large sums paid in the name of goodwill and IC resources. That implies that it is a large number of acquisitions driven by the need to obtain intellectual capital resources. In acquisitions with such a motive, the expected synergistic effect depends on the acquirer's ability to assess the power of the intangible assets acquired (Marr et al. 2003). In order for such acquisitions to be successful, an adequate and specific combination of the firm's internal and purchased strategic assets needs to be made. That requires an understanding of the very nature of the intangible assets, how they complement each other and their roles in strengthening the competitive position of the acquirer. First of all, the acquirer should be able to adequately assess its intangible assets and the assets of the acquired firm. Marr et al. (2003), notices that current practice shows that the process of valuing these assets has been a great challenge for many firms. Reports from "Vodaphone", "Vivendi", "Marconi", "AOL-Time Warner" and many others confirmed post-acquisition massive goodwill write-offs and high post-acquisition restructuring costs, which could reach billions of dollars. Marr at al. (2003) argues that adverse post-acquisition situations are the result of failure to evaluate intangible assets during the acquisition process itself, as well as poor planning of the post-acquisition business strategy. Without the proper assessment, measurement and valuation of IC, the acquirer may overestimate the assets of the IC of the acquired firm, resulting in a direct impairment of its own business. Also, the period of integration of the two firms that comes after the official takeover is very complex and full of different challenges. In this period, there is a high risk of failure to create a new IC through innovation. 
140 | MEASUREMENT OF INTELLECTUAL CAPITAL: THEORETICAL AND EMPIRICAL FRAMEWORK

\subsection{IMPROVING STAKEHOLDER COMMUNICATION}

The second group of motives relates to improving the communication of the firm with the stakeholders. What the authors cite in this context as reasons for measuring IC are: reducing information asymmetry, providing information about the real value of the firm and its ability to achieve high performance in the future, improving the firm's ability to raise funding, enhancing its reputation and influencing the determination of the firm's market valuation.

One of the motives for measuring IC and publicly disclosing the results of its measurement in the form of public reports is the need to explain the growing difference between the market value and the book value of an organisation. The fact that there is a growing gap between these two values does not make the financial statements less important, since the balance sheet's objective is not to approximate the market value of the firm, nor is it the purpose of measuring and recording intangible assets. The misconception that entering intangible assets into the balance sheet would balance book and market value comes from statements by some authors that the difference between market and book values reflects intellectual capital (Edvinsson and Malone 1997, Stewart 1997; Sveiby 1997). However, those authors were stressing that in a contemporary economic environment which is intensively based on knowledge, intellectual capital more and more determines the market value of the firm and that the increasing gap between market and book value indicates the need to supplement the financial statements with complementary reports on intellectual capital. Not only is there no need to equalise these two values, but also it is not possible. Andriessen (2004), believes that attributing the difference between market value and book value to intellectual capital is the same as comparing the difference between apples and oranges with a banana.

At the beginning of 1991, the Jenkins Committee, a special committee on financial reporting, was formed in the United States with the task of proposing ways to improve the quality of public business information. After surveying the needs of the users of business informations (professional investors, creditors and financial advisers), the Committee concluded that in order to meet the needs of users, the financial statements must include: more information on the firm future activities (strategic plans, identified business opportunities, risks), information about factors that create long-term value and measures that show how business processes are performed. Also, the information in the public reports needs to be aligned with the information used to manage the business (American Institute of Certified Public Accountants - AICPA , 1994). In April 1996, the US Securities and Exchange Commission (SEC) held a meeting concluding that an increasing number of businesses whose assets are mostly made up of intangible assets are emerging in the financial market. Because these assets are not visible in the financial statements, there 
are not visible to the public. What the SEC was anxious about was the fact that these "new" companies were selling at a price far more than their book value (the value of their tangible assets). The SEC assumed that because of the dominance of intangible resources in the overall structure of the resources of these companies, the market attributed much higher value to these companies than that reported in their balance sheets (Securities and Exchange Commission - SEC, 2000). All this is implying on financial and capital markets growing information asymmetry. The lack of information on intangible assets of the firm causes a significant asymmetry of information, which increases the risk of investment. Investors (especially small ones) can not receive any information about the status of the firms IC, its value, the way it was created and used to generate profits, or its future potential. Investors who would gain insight into information about investments in intangible assets and the expected return on these investments would gain an advantage over others. Another thing is that the firms whose assets are mostly intangible face more difficult access to finance. That is because tangible assets represent possible collateral for banks and intangible do not. Also, the inability to access information about intangible assets and their value can lead to an underestimation of the firm's value with a rich portfolio of intangible resources. Therefore, in order to create a more realistic perception of their real value, the firms with rich IC portfolio show considerable interest in publishing information about it.

Leadbeater (1999), exploring the hypothesis that firms whose asset portfolio is dominated by intangible assets, in the capital market face higher capital costs compared to the firms that own higher levels of tangible assets, concluded that such a situation is due to uncertainty, i.e. the unreliability that accompanies investors perception of intangible assets. Mavrinac and Siesfeld (1997), pointed on a survey of the UK capital market which results have shown that most CFOs of listed companies believe that their shares have been undervalued in recent years. More than a third of companies stated that the price of their shares for at least six months during the year deviated from what they perceived as fair value. Also, 84 per cent said their share price was either too low or too high for a specified period. Most analysts included in this study stated that better communication between firms and the capital market would contribute to better stability in the market value of the shares. Results of these studies indicate that investors and analysts consider the information on firms intangibles important for the assessment of firms market value. Consequently, one of the motives for the firms to measure their IC and to report on it is to achieve a more realistic value for their shares, to stabilise that value, and therefore to get access to more favourable prices of capital. 
142 | MEASUREMENT OF INTELLECTUAL CAPITAL: THEORETICAL AND EMPIRICAL FRAMEWORK

\section{BENEFITS OF IC MEASUREMENT FOR THE FIRMS}

Considering the previously mentioned reasons for IC measurement, firms measure their IC primarily for strategic reasons. Measurement of IC is an instrument for identifying and mapping intangible assets. It allows insight into the relationships that exist between IC components and their flow matrices through which those components create value. Through the information they receive from measuring IC, managers can evaluate the effectiveness and efficiency of firm intangible strategic resources, constantly monitor their value and develop them in the desired direction.

Measurement of IC also enables: Setting priorities related to the issue of organisational knowledge creation; Accelerating learning within the organisation; Identification of best practice and its dissemination along the organisation; Improving understanding of how knowledge influences the creation of internal relationships; Understanding organisational social networks and identifying agents that drive change; Growth of innovation capabilities; Building an employee's perception about organisation and Growth of employee motivation to build a result-oriented culture.

Since measuring of the IC contributes to aligning firm IC resources with strategic vision, identifying the matrices of intangible assets interactions which lead to value creation, designing business processes by these matrices, effectiveness in implementing a value creation strategy and building competitive advantage, it is an inseparable element of firm's strategy based on the concept of IC. Implementation of IC measurement system contributes significantly to the decision-making process because it allows managers to base their decisions on comprehensive and relevant information. The implementation of an IC measurement system requires from firm to know how to: classify its IC assets, identify how they support strategic goals, quantify their contribution to value creation, and compare them with those of competitors.

\section{THE IC MEASUREMENT ISSUES}

In the last fifteen years, a large number of IC measurement methods have been presented. However, the various determinants which are placed along with the name of the method (evaluation, financial evaluation, measurement, estimation), suggest various approaches to the identification of the value of IC. The complexity of measuring IC determines several facts. First, some intangibles, such as creativity cannot be measured. Creativity, which lies at the core of creating new knowledge and innovation, is an unpredictable process with unpredictable results. The second reason is that the nature of intellectual capital is idiosyncratic, which implies that what is valuable and useful for one firm for 
another may be worthless. That requires the application of different measurement systems and indicators and makes it impossible to standardise it. Third, the measurement of IC is also hindered by two dimensions of intellectual capital: static and dynamic. Starovic and Marr (2010), pointed out that intangible resources and intangible activities need to be distinguished, thus shedding light on the static and dynamic character of intellectual capital. Intangible resources, of a static nature, can be measured at any time. Employee competencies (human capital), intellectual property rights (structural capital), customer satisfaction or supplier agreements (relational capital) can all be considered within this category. However, since the IC creates value based on the dynamic interaction of its elements, it needs to be also considered in dynamic terms. The firms carry out targeted activities regarding the acquisition of the intangible resources (through internal development or outsourcing), their monitoring, measurement and commercialisation. These dynamic activities affect the allocation of resources, but their contribution can not be quantified financially. Because the dynamic character of intellectual capital implies that the interaction of its components creates value, this implies that it is often not possible to value its components, for themselves, but intellectual capital as a whole. Fourth, unlike financial capital, the unit of measurement of intellectual capital is not unique, which is another problem related to the measurement of IC. It is precisely because of this problem that in IC measurement, approximate measures are used, which reflects some of the characteristics of firms IC portfolio. Fifth, the problem is to identify the resources that should be measured. These are the resources which are often not consciously articulated and classified by firm despite their strategic importance. Through these resources, a firm builds its core competencies and capabilities that enable it to achieve its strategic goals.

Ross (2005) points out that the most important thing is that the IC measurement method should meet the needs of all stakeholders in a verifiable, useful and safe way. If managers need to base decisions on performance measurement methods, the information provided by those methods must be verifiable and reliable. Even if the interpretation of this information may be subjectively different, its source must be undoubted. He, therefore, believes that it is necessary to fulfil the following conditions for the creation of a relevant system of measuring business performance and they are completeness, clarity, independence, compliance.

The most common drawback of IC measurement methods is that they record the presence of resources, not their potential for value creation. Value is created when resources are used and destroys when resources are left unused. If gaining insight into the value creation process is a goal in itself, the attributes to be measured are the influences that the employed IC elements exert in the value creation process. 
144 | MEASUREMENT OF INTELLECTUAL CAPITAL: THEORETICAL AND EMPIRICAL FRAMEWORK

Besides, if an attempt is made to determine the relative value of IC elements, then it is necessary to quantify not only the IC elements that influence the value creation but also the effects of their transformation. That is necessary because the transformation of IC elements does not in itself imply created value or impact on value creation. Therefore, value assessment requires knowledge of the effect of resource transformation and the impact that transformation exerts. According to the concept of IC, the process of value creation is not a linear, sequential process, but a process that is formed in the dynamic interconnection and interdependence of many factors, so that value creation is viewed from a holistic perspective. The specificity of intangible assets is that they create value in their interaction, so it is difficult to separate them from one another. Among the categories of human and structural capital, as well as their subcategories, there are different flows of different dynamics and intensities that lead to the transformation of IC into financial capital and vice versa. Therefore, the monitoring of these flows is critical, because that is the only way how the firm can gain insight into which IC flows contribute to the value increase and which do not. Designing mechanisms for monitoring interactions between IC resources should contribute to a better understanding of the interdependence, dynamic exchange, feedback effects and all complexities that exist in their interactions. This conscious, systematic approach to understanding and managing the value creation process represents the very essence of the Concept of Intellectual Capital.

\section{IC INDICATORS AND CRITERIA FOR THEIR RELEVANCE}

An indicator is defined as an absolute or relative parameter, which describes a particular opportunity or circumstance. Comparability of parameters depends on whether it is clearly defined, whether it is always calculated in the same way and whether a framework for its interpretation is available (Arbeitskreis, 2004). Intellectual capital indicators are approximate measures of influential components of intellectual capital. The values of IC indicators are generally expressed numerically. By calculating the numerical values of the indicators, the defined influential components of the IC are measured and monitored, that is, the intellectual capital of the firm is measured. Typically, when defining appropriate indicators, multiple indicators are identified for an individual IC component, as different indicators may contain relevant information about the same component. Indicators from already existing internal company reports, such as management results, employee results (HR department reports), or marketing department research information, information on corporate responsibility, or new strategic partnerships or new clients can also be used. In determining the values of indicators, data sources are critical. They are used to calculate indicators of numerical values. 
Roberts (1998), stresses that the point of measuring intellectual capital is to use the indicators to discover intangible resources and processes that create value, as well as ways in which it is possible to manage these processes efficiently. Therefore, the precision of the measurement and the usability of the information obtained by measuring the IC depend primarily on the defined indicators. In the context of defining IC indicators and their use, it is essential to distinguish between concepts of efficiency and effectiveness, which are often used as synonyms while implying two different contexts. Effectiveness binds outputs to specific goals set for an operation, while efficiency is related to the adequate use of input resources. Efficiency is a quantitative measure, while effectiveness is a qualitative measure. Thus, implementing performance measurement systems characterised by mostly efficiency or effectiveness concept carries the strategic implications of how an organisation has chosen to evolve and grow in the future.

\subsection{THE RELEVANCE OF IC INDICATORS}

Regarding the criteria for the relevance of IC indicators, relevant IC indicators are those that measure what is most important to phenomena. In the case of intellectual capital, the relevant indicators measure the influential critical factors of human, structural and external capital, that is, intangible resources that are of strategic importance to the organisation. For the indicator to be relevant, its definition must make sense and must meet usefulness and technical criteria (MERITUM, 2001).

The usefulness of the indicators. The usefulness of the indicator is maintained by whether the indicator contributes to the achievement of the set goal through the object of measurement, that is, whether it gives an insight into how intellectual capital creates value. In order for IC to create maximum value, it is necessary to make it visible. In the search for meaningful indicators, it is necessary, first of all, to identify the key strategic assets of the organisation and to discover the matrix by which they create value. The purpose of intellectual capital measurement is to discover value-generating factors that are not covered by traditional measurement systems. Value creation refers to the processes and connections between what happens in one part of the organisation and results in another part of the organisation. Each indicator should contribute to discovering the hidden processes that create value. Identifying these cause-and-effect relationships is also the hardest part of the job when defining IC indicators.

The content of intellectual capital and how it is transformed into an added value is specific for each organisation. Therefore, it is not possible to identify a general group of relevant indicators for measuring intellectual capital, which would be appropriate for all organisations. Because what matters to one organisation may not matter to another. The group of relevant indicators for measuring intellectual capital is determined by the strategic goals and influential critical factors of the intellectual 
146 | MEASUREMENT OF INTELLECTUAL CAPITAL: THEORETICAL AND EMPIRICAL FRAMEWORK

capital of the firm. That is why groups of general indicators are proposed in methods for measuring intellectual capital. As meaningful IC indicators are those that identify and describe strategically important resources and processes, to define these indicators, it is necessary to reach a consensus on what is essential to the firm. The firm should determine whether it possesses the necessary competencies and skills and if it possesses both, to what extent it possesses them. The firm should also identify the essential value creation processes and classify them according to their importance.

Technical criteria for indicators. The role of IC indicators is to make firms invisible resources visible, illustrate and measure them. Roberts (1999) provides the following essential technical criteria for indicators: precision, objectivity, timeliness, simplicity.

In order for IC indicators to be relevant, they must be adequate and meet the criteria of precision, objectivity, timeliness and simplicity outlined above. When defining relevant indicators and their purpose, there must be consensus at all organisational levels about what is vital to the organisation. Also, since the IC concept views an organisation through a state of permanent change and taking into account the dynamic character of IC, a system of relevant indicators must be able to monitor intellectual capital flows. The process of identifying relevant indicators must focus on the flow of intellectual capital and changes in its characteristics. Changes in indicators must accompany changes in the knowledge process underlying each defined indicator. In a context of rapid change, in which knowledge is rapidly becoming obsolete and in which something important today may become irrelevant, it requires a continuous review of the relevance of the indicators and their redefinition.

\subsection{IC INDICATORS AS FLOW INDICATORS}

Intellectual capital changes with each use of knowledge as well as in the learning process. At the organisational level, it changes with each new knowledge or information. Intellectual capital management involves managing the flow of knowledge. That means that indicators should have a dynamic character, i.e. to represent change, but also to adapt to change. Indicators, to meet the previous criteria, should represent flows, not stocks of intellectual capital. For example, the statement that a company has 150 internally developed patents in its portfolio and 50 patents purchased says less about the firms IC than the information that the firm has continuously increased the number of internally created patents by 70 per cent over the last ten years. This other information indicates that the firm IC is continuously increasing. The dynamic nature of IC is also determined by the mode of its creation, characterised by intense interaction between its components (human, structural and external capital). Because IC is created 
within a dynamic interaction between its constituent elements, it cannot be expressed by a finite number. Adopting a dynamic perspective involves not only measuring the flows of intellectual capital, but also a specific frequency of changes in the measures/indicators themselves.

It is imperative that employees, based on indicators, can understand the essence of intellectual capital and the value creation process of their firm, a strategy based on the concept of IC, and the need for change in order to realise that strategy. When employees know what is important, what is expected of them, and what their role is, they can look at their contribution and ways they can contribute to improving the firm performance.

\section{APPROACHES TO MEASURING IC}

Kannan and Aulbur (2004), points out four general approaches to IC measurement. Depending on the approach and the subject of IC measurement, they distinguished financial approach, the perceptual approach, the process approach, and the approaches that fall under others. The approaches outlined are summarised below ${ }^{1}$.

A financial approach. This approach is aimed at developing measures that will provide the firm and its shareholders with information about the financial value of the firm's intangible assets. By linking the IC development process to the financial inputs and outputs associated with these processes, one can get an idea of the efficiency of the use of intellectual capital. The measures have been developed to link investments in intangible assets and profits.

A perceptual approach. This measurement approach is aimed at measuring employees 'perceptions of the firm's organisational processes. It involves measuring the satisfaction of employees with the work of top management, their perception of the need to disseminate knowledge and knowledge management, the perception of how to create and added value, and of a fair reward system. In this approach, organisational culture is seen as a significant factor in positively influencing employee behaviour. Consequently, analysing organisational culture is key to understanding the knowledge flow within the organisation. When individuals are encouraged to express their beliefs and knowledge publicly, tacit knowledge becomes explicit. Perceptual measures include needs analysis, culture analysis, and the analysis of the employee commitment to organisational goals. Assessment of these aspects is essential because it helps to gain insight

\footnotetext{
${ }^{1}$ For detail explanation of these approaches see: Kannan,G., \& Aulbur, G.W. (2004). Intellectual Capital: Measurement effectiveness. Journal of Intellectual Capital, 5(3), 389-413.
} 
148 | MEASUREMENT OF INTELLECTUAL CAPITAL: THEORETICAL AND EMPIRICAL FRAMEWORK

into an organisation's willingness to truly engage in knowledge management activities and its commitment to developing its IC.

The process approach to measuring IC is aimed at measuring the efficiency of organisational processes, so these measures can be used to diagnose the efficiency of using IC. They are used to define and map organisational processes. They can be used to define the infrastructure needed for firms development as well as shorten the production cycle and learning time.

Other approaches to IC measurement. These approaches include measures related to the evaluation of social networks and measures of the potential value of knowledge. Social networking measures are aimed at determining the optimal allocation of intangible assets and using them to increase the degree of innovation. Kannan and Aulbur (2004) referring to Carley, Yuqinq and David (2000), points that they relate to the measurement of interpersonal networks and authoritative structures. Examples of these measures are the scope of control, which implies the average number of top managers' connections with lower organisational levels; the density resulting from dividing the existing network links by the number of all possible network links, the cognitive load per person that is obtained by putting the number of people with whom the person interacts with the total number of people in the network etc. The degree of innovation can be measured based on the time elapsed from the beginning to the completion of a particular innovation and its implementation in the context of replacing an old technique or technology as well as the added value that the innovation has created. Iske (2005) designed knowledge value potential measures. These measures help to make an investment decision and plan for IC growth. The potential of knowledge equals the sum of the possibilities that knowledge is related to the context, which is multiplied by the ease of its transfer and use, as well as the added value derived from the specificity of its context. Knowledge potential is context-dependent and influenced by social factors, interactions and behaviour.

As can be understood, the above approaches to IC measurement measure only particular aspects of IC or certain aspects in which these resources contribute to value creation. They are individually unable to shed light on the dynamics of organisational resource behaviour and their impact on its performance. Kannan and Aulbur (2004) believe that measuring intellectual capital requires an integrated approach which will integrate financial with perceptual and process/system measures of IC. By linking process, perceptual and financial measures, an organisation can measure its overall IC. For such an integrated approach, it is necessary to have an insight into each organisational unit or each external entity included in the existing value network. 


\section{IC MEASUREMENT METHODS}

As it is mentioned, depending on the approach to measuring IC, different types of measures are developed: financial measures, perceptual measures, process measures and other measures. Also, various IC valuation methodologies have been developed. Andriessen (2004) reviewed the 25 methods for IC measurement and grouped them under four categories: Financial Valuation, Value Measurement, Value Assessment, and Measurement. The most widely accepted framework for the classification of IC measurement methods is one given by Sveiby (2010). Sveiby classified the IC measurement methods under four categories: Direct IC methods, Market capitalisation methods, Return-onassets methods (ROA), and Scorecard methods. According to Sveiby (2010), Intellectual Capital Measurement Methods first can be grouped into intellectual capital valuation methods and methods for measuring intellectual capital. The detail list and explanation of the methods that will continue to be presented in this paper can be found in Sveiby paper „Methods for Measuring Intangible Assets“ in his web-site (https://www.sveiby.com/files/pdf/intangiblemethods.pdf).

\subsection{INTELECTUAL CAPITAL VALUATION METHODS}

Intellectual capital valuation methods assess the financial value of the IC, and the intellectual capital value is expressed in monetary form. Since these methods allow for the estimation of the real value of the firms, they are used in mergers and acquisitions, as well as for their cross-industry comparison. Depending on whether intellectual capital at the organisational level is assessed directly or indirectly (value is determined indirectly by identifying and evaluating individual components and categories of intellectual capital), this group of methods Sveiby further classify into methods of direct assessment of intellectual capital, Intellectual capital valuation methods based on market capitalisation and Intellectual capital valuation methods based on ROA index.

Direct assessment methods. Direct IC measurement methods estimate the value of intellectual capital in monetary units. These methods, first, identify the

components of intellectual capital that are relevant to the financial evaluation of its values, and then the financial processes are evaluated for each of the identified components. Some of these methods express the value of intellectual capital as a set of values of its all identified components, while some of them express IC value through an aggregate index that represents a financial estimate of its total value. Most of these methods seek to capture the firm's total intellectual capital. Their focus is on the market elements of IC: external capital in the form of customer loyalty, human capital in the form of investment in education and 
150 | MEASUREMENT OF INTELLECTUAL CAPITAL: THEORETICAL AND EMPIRICAL FRAMEWORK

training and structural capital in the form of patents, technological assets, knowhow and information systems.

IC Valuation methods based on market capitalisation. Market capitalisation methods estimate the financial value of intellectual capital indirectly, based on the difference between the firm market value and its book value (the nominal value of its shares).

IC valuation methods based on ROA index. ROA methods take the average profit, before tax, for a period of three to five years. Then the average profit is divided by the average value of the firm's tangible assets calculated for the same period. Then, the ROA score is compared to the industry average in which the firm operates to make a difference. If the difference is zero or negative, it is assumed that the firm has not created an added value based on the IC compared with the industry average, so the value of the IC is assumed to be zero. If the difference with the industry average is shown to be positive, then it is assumed that the firm has created added value based on IC. That positive difference is then multiplied by the average value of the firm's tangible assets in order to calculate the average annual income from intangible assets. By dividing this income by the average cost of capital, IC values are obtained.

\subsection{METHODS FOR MEASURING INTELLECTUAL CAPITAL}

Methods for measuring intellectual capital measure IC using non-monetary criteria. Sveiby (2010), believes that these methods are more useful than methods for assessing the value of intellectual capital because knowledge flows and intangible assets are intrinsically of non-financial nature. Some of these methods apply value scales (methods for measuring the value of intellectual capital), that is, measure the intellectual capital value through non-monetary criteria. Since those methods are used to produce reports on firms' intellectual capital, Sveiby calls them IC reporting methods or Scorecard methods. Those methods are used for detail reporting on IC. The authors of these methods assume that knowledge flows and intangible assets are intrinsically non-financial, which is why they measure intellectual capital through non-monetary criteria. Within this group of methods, only the IC Index and Business IQ methods measure intellectual capital at the organisational level. Other methods identify different components of intellectual capital, for which appropriate indicators are further generated. The corresponding numerical values for each selected indicator are entered into the report, or they are presented graphically. These methods are intended to monitor the flow of intellectual capital, that is, its changes and changes in its components over time. In the final report, they combine intellectual capital and traditional financial indicators to provide a comprehensive picture of the firm business performance. 


\subsection{ADVANTEGES AND DISADVANTEGES OF IC MEARUSREMENT METHODS}

IC measurement methods have their advantages and disadvantages. Methods aimed at expressing the monetary value of IC, such as ROAs and market capitalisation methods, are useful in situations of acquisition and merger, as well as for the firm market valuation. They can also be used to benchmark companies, as well as to illustrate the financial value of intangible assets. These methods have often been criticised for their static nature and their inability to capture the impact of underlying factors that influence the development and growth of IC.

The advantages of direct IC measurement and reporting methods are that they can provide a more comprehensive diagnosis of the condition of the organisation. Also, they are applicable at all organisational levels. By their nature, these methods are more detailed, and their focus is on monitoring the key activities of an organisation, so the information provided by these criteria can be faster and more accurate than those obtained by the financial criteria. These methods use units of measure that correspond to each IC component. For example, market share, the value of patents or the number of competencies all have their separate units of measurement. Besides, different measures have different relevance and utility concerning different organisational levels. These measures must be aligned in the way to reflect the common understanding of organisation purpose and direction in which it is going. The disadvantage of these methods is that indicators depend on the context and must be tailored and defined according to the specificities of each firm, which makes a sectorial comparison between firms almost impossible. Also, since the perceiving a firm's performance through a purely financial perspective is still dominant in practice, new methods which include intangible assets are not yet widely accepted by managers. A potential disadvantage of these methods is that managers find them too complicated because their comprehensiveness requires the collection of large amounts of data that are difficult to generate and present.

Generally speaking, the major disadvantage of most methods for measuring IC is that they record the presence of IC resources, not their potential for value creation. Value is created when IC resources are used and destroyed when they are left unused. If gaining insight into the value creation process is a goal in itself, the attributes to be measured are the influences that the employed IC elements exercise in the value creation process. Besides, if an attempt is made to determine the relative value of IC elements, then it is necessary to quantify not only what influences the value creation but also the effects of the transformation of the IC elements. That is necessary because the transformation of the IC elements does not, by itself, imply value created, nor does it exert influence on value creation. For this reason, IC valuation requires knowledge of the effect of resource transformation and the impact that transformation 
152 | MEASUREMENT OF INTELLECTUAL CAPITAL: THEORETICAL AND EMPIRICAL FRAMEWORK

exerts. From all of the above, it can be concluded that none of the existing methods can meet all the qualitative criteria fully or to serve all the specific needs of the firm. Therefore, the firm should choose the appropriate method according to the purpose of measuring the IC, its specific strategic goals and users for whom the IC information is intended.

\section{CONCLUSION}

Compared to all other aspects of the development of the IC concept, IC measurement is the most problematic one. Generally, IC measurement aims at enabling managers to effectively manage the firm through the relevant IC management information system. IC management information system allows the development of a firm strategy based on strategic resources or knowledge. Also, IC measurement can be used for the public presentation of the firm, thanks to which the firm can describe itself, its performance, its market position and its development potential to all interested stakeholders: clients, creditors, shareholders, business environment and society as a whole. Based on this information, stakeholders can assess the quality of firms management and its potential to be a reliable supplier or a credible borrower in the future. Likewise, by reducing information asymmetry, disclosure of IC information should reduce the cost of capital by reducing uncertainty about the future performance of the firm and facilitating its more accurate valuation.

The need for managers and the financial community to adapt to new systems of performance measurement and reporting focused on intangible assets represents the critical point and subject of intensive discussions concerning the future development of the IC concept. So far, a large number of IC measurement methods have been created, developed either by firms or experts and scientists. That fact clearly shows that firms understand that they need to measure their IC, especially if one considers that implementing the IC measurement process is neither a simple nor a cheap process. There is also a discussion about the need for further research into the quality of IC information obtained through the use of existing measurement methods used for IC external reporting. In this regard, the transparency and reliability of IC information, as well as their susceptibility to audit, are discussed. On the other hand, the capital market, the accounting community and regulatory bodies also point to the urgent need to develop these activities and to try to regulate them. Researches in the domain of IC public reporting indicates the trend of a constant increase in the number of published information on intellectual capital in the form of supplements to the firms regular annual financial statements, as well as within their IPO prospectuses. That points to the fact that businesses, investment advisers and the investment community believe that this information is of great importance for the firm's valuation by the capital market. 
Seen from a strategic perspective, a conscious and systematic approach to identifying and monitoring the value creation process through the measurement of firms IC can eliminate the risk of misallocation of resources or inadvertent disruption of a specific combination of resources that is responsible for creating firms value. The importance of managing and measuring IC for improvements in the firm's value creation process is confirmed by empirical evidence. This evidence indicates that firms have been able to develop management processes that have transformed the results obtained by measuring their IC into necessary and concrete management activities that have contributed to the improvement of value creation processes. In this sense, the management of intellectual capital and its measurement should be seen as two inseparable processes. What is certain is that intellectual capital will never be possible to measure in the traditional way. Since intellectual capital is fundamentally based on tacit knowledge, which organisations, according to their capabilities, manage to articulate, codify, incorporate into processes and commercialise to a greater or lesser extent, it can never be measured as a whole, nor can it be done using traditional economic parameters. Therefore, a formula that answers the question of how much an intellectual capital of a firm is worth does not exist, nor will it ever exist. However, this does not mean that the methods developed to evaluate and record IC are not meaningful and useful. The strategic importance of measuring IC cannot be called into question. In this sense, identifying and tracking the resources and processes that are responsible for developing a firm's intellectual capital may be more critical than finding its value.

\section{REFERENCES}

Abdolmohammadi, M. J. (2005). Intellectual capital disclosure and market capitalization. Journal of Intellectual Capital, 6(3), 397-416.

Achten, J. H.J. (1999). Transparency in intangible production assets. Paper presented at the International Symposium Measuring and Reporting Intellectual Capital: Experiences, Issues and Prospects. Amsterdam.

Ahmed, K., \& Courtis, J. K. (1999). Associations Between Corporate Characteristics and Disclosure Levels in Annual Reports: A MetaAnalysis. The British Accounting Review, 31(1), 35-61.

American Institute of Certified Public Accountants-AICPA. (1994). Improving Business Reporting: A Customer Focus. New York: AICPA

Andriessen, D. (2004). Making sense of intellectual capital: Designing a method for the valuation of intangibles. Burlington, USA: Elsevier Butterworth-Heinemann. 
154 | MEASUREMENT OF INTELLECTUAL CAPITAL: THEORETICAL AND EMPIRICAL FRAMEWORK

Andriessen, D., Frijlink, M., van Gisbergen, I., \& Blom, J. (1999). A core competency approach to valuing intangible assets. Paper presented at the International Symposium Measuring and Reporting Intellectual Capital: Experiences, Issues and Prospects. Amsterdam.

Arbeitskreis, W. (2004). Intellectual capital statement - Made in Germany: guidelines, Federal Ministry of Economics and Labour. Retrived from http://www.akBilans znanja.org/ Infoservice/ Infomaterial/Leitfaden_english.pdf.

Beaulieu, R. P., Williams, M. S., \& Wright, M. E. (2002). Intellectual Capital Disclosures in Swedish Annual Reports. In Bontis, N., (Ed), World Congres on Intellectual Capital Readings (pp. 135-153). MINT Research Centre, McMaster University, Butterworth-Heinemann.

Bontis, N. (2000). Assessing Knowledge Assets: A Review of the Models Used to Measure Intellectual Capital. Closing Keynote Presentation at the KM World 2000. Santa Clara, California.

Bornemann, M., Knapp, A., Schneider, U., \& Sixl, K. I. (1999). Holistic measurement of intellectual capital. Paper presented at the International Symposium Measuring and Reporting Intellectual Capital: Experiences, Issues and Prospects. Amsterdam.

Botosan, C. (1997). The impact of annual report disclosure level on investor base and the cost of capital. The Accounting Review, 72, 323-350.

Brennan, N. (1999). Reporting and managing intellectual capital: evidence from Ireland. Paper presented at the International Symposium Measuring and Reporting Intellectual Capital: Experiences, Issues and Prospects. Amsterdam.

Bukh, P. N. D., Larsen, H. T., Gormsen, P., \& Mouritsen, J. (2001). Disclosure of intellectual capital indicators in Danish IPO prospectus. Aarhus: Aarhus School of Business.

Canibano, L., Garcia-Ayuso, M., Sanchez, M. P., Chaminade, C., Olea, M., \& Escobar, C. G. (1999). Measuring intangibles: discussion of selected indicators. Paper presented at the International Symposium Measuring and Reporting Intellectual Capital: Experiences, Issues and Prospects. Amsterdam.

Carley, K. M., Yuqing, R., \& David, K. (2000). Measuring and modelling change in C $3 \mathrm{I}$ architecture. In Proceeding of the 2000 Command and Control Research and Technology Symposium. Naval Postgraduate School, Monterey, CA. 
Chan, K. H. (2009). Impact of intellectual capital on organizational performance: an empirical study of companies in the Hang Seng Index. The Learning Organization, 16(1), 4-21.

Chen, M. C., Cheng, S. J., \& Hwang, Y. (2005). An empirical investigation of the relationship between intellectual capital and firms' market value and financial performance. Journal of Intellectual Capital, 6(2), 159-176.

Chu, S. K. W., Chan, K. H., \& Wu, W. W. Y. (2011). Charting intellectual capital performance of the gateway to China. Journal of Intellectual Capital, 12(2), 249-276.

Danish Agency for Trade and Industry - DATI. (1998). Intellectual Capital Accounts: New Tool for Companies. Copenhagen: DATI Council.

Danish Agency for Trade and Industry. (2001). A Guideline for Intellectual Capital Statements: A Key to Knowledge Management. Danish Agency for Trade and Industry, Copenhagen.

Danish Agency for Trade and Industry. (1999). Developing Intellectual Capital Accounts. Experiences from 19 Companies. Ministry of Business and Industry, Copenhagen.

Danish Trade and Industry Development Council. (1997). Intellectual Capital Accounts: Reporting and Managing Intellectual Capital. Danish Trade and Development Council, Copenhagen.

Edvinsson, L., \& Malone, M. S. (1997). Intellectual Capital: The Proven Way to Establish Your Company's Real Value by Measuring Its Hidden Brain Power. London: Piatkus.

Edvinsson, L., \& Richtner, A. (1999). Words of value - giving words to IC. Stockholm: Skandia.

Financial Accounting Standards Board -FASB. (2001). Disclosure of Information about Intangible Assets Not Recognized in Financial Statements. FASB, Norwalk, CT.

Firer, S., \& Williams, S. M. (2003). Intellectual capital and traditional measures of corporate performance. Journal of Intellectual Capital, 4(3), 348-360.

Grant, R. M. (1991). The resource-based theory of competitive advantage: implications for strategy formulation. California Management Review, 33, 114- 135.

Guthrie, J., Petty, R., Ferrier, F., \& Well, R. (1999). There is no accounting for intellectual capital in Australia: review of annual reporting practices and 
156 | MEASUREMENT OF INTELLECTUAL CAPITAL: THEORETICAL AND EMPIRICAL FRAMEWORK

the internal measurement of intangibles within Australian organisations. Paper presented at the International Symposium Measuring and Reporting Intellectual Capital: Experiences, Issues and Prospects. Amsterdam.

Helmi, M. A. (1998). Measuring the effect of customer satisfaction on profitability: a challenging role for management accountants. The National Public Accountant, 43(10), 8-11.

Hoogendoorn, M., de Bos, A., Krens, F., Veerman, W., \& Beek, H. (1999). Transparency in intellectual capital. Paper presented at the International Symposium Measuring and Reporting Intellectual Capital: Experiences, Issues and Prospects. Amsterdam.

Iske, P. (2005). Connected brains: Question and answer systems for knowledge sharing: concepts, implementation and return on investment. Journal of Knowledge Management, 9(1), 126-145.

Ittner, C. D, \& Larcker, D. F. (1998). Are nonfinancial measures leading indicators of financial performance? Customer satisfaction analysis. Journal of Accounting Research, 36.

Johanson, U., Martensson, M., \& Skoog, M. (1999). Measuring and managing intangibles: 11 Swedish exploratory case studies. Paper presented at the International Symposium Measuring and Reporting Intellectual Capital: Experiences, Issues and Prospects. Amsterdam.

Kamath, G. B. (2008). Intellectual capital and corporate performance in Indian pharmaceutical industry. Journal of Intellectual Capital, 9(4), 684-704.

Kannan, G., \& Aulbur, G. W. (2004). Intellectual capital: Measurement effectiveness. Journal of Intellectual Capital, 5(3), 389-413.

Kaplan, R. S., \& Norton, D. P. (1992). The balanced scorecard measures that drives performance'. Harvard Business Review, 70(1), 1-9.

Kaplan, R. S, \& Norton, D. P. (1996). The Balanced Scorecard - Translating Strategy into Action. Boston, MA: Harvard Business School Press.

Komnenic, B., \& Pokrajcic, D. (2011). Intellectual capital as a valuable driver of corporate performance: Empirical research on the banking sector in Serbia. International Journal of Arts \& Sciences, 4(9), 283-298. 
Biserka Komnenić, Jovan Njegić | 157

Komnenic, B., \& Pokrajcic, D. (2012). Intellectual capital and corporate performance of MNCs in Serbia. Journal of Intellectual Capital, 13(1), 106-119.

Kooistra, J. M., \& Zijlstra, S. M. (2001). Reporting on intellectual capital. Accounting, Auditing \& Accountability Journal, 14(4), 456-476.

Kujansivu, P., \& Lonnqvist, A. (2007). Investigating the value and efficiency of intellectual capital. Journal of Intellectual Capital, 8(2), 272-287.

Leadbeater, C. (1999). New measures for the new economy. Paper presented at the International Symposium Measuring Reporting Intellectual Capital: Experiences: Issues and Prospects. Amsterdam.

Lev, B. (2001). Intangibles: Management, Measurement, and Reporting. Washington DC: Brookings Institution Press.

Marr, B., \& Chatzkel, J. (2004). Intellectual capital at the crossroads: managing, measuring, and reporting of IC. Journal of Intellectual Capital, 5(2), 224-229.

Marr, B., Gray, D., \& Neely, A. (2003). Why do firms measure their intellectual capital?. Journal of Intellectual Capital, 4(4), 441-464.

Marr, B., Neely, A., \& Thomas, G. (2002). Balanced scorecard and strategy maps: how intangibles drive corporate performance at Shell International. In Proceedings: PMA 2002 - Research and Action. Boston, MA.

Marr, B., \& Schiuma, G. (2001). Measuring and managing intellectual capital and knowledge assets in new economy organisations. In Bourne, M. (Eds), Handbook of Performance Measurement. London: Gee.

Martson, C. L., \& Robson, P., (1997). Financial reporting in India: Changes in Disclosure over the period 1982-1990. Asia- Pacific Journal of Accounting, 4(1), 109-139.

Mavrinac, S., \& Siesfeld, T. (1997). Measures That Matter. An Exploratory Investigation of Investors' Information Needs and Value Priorities. Cambridge, MA: Ernst \& Young Center for Business Innovation.

MERITUM project final report. (2001). Measuring Intangibles to understand and improve innovation management.

Miller, M., Du Pont, B. D., Fera, V., Jeffrey, R., Mahon, B., Payer, B. M., \& Starr, A. (1999). Measuring and reporting intellectual capital from a diverse Canadian industry perspective. Paper presented at the 
158 | MEASUREMENT OF INTELLECTUAL CAPITAL: THEORETICAL AND EMPIRICAL FRAMEWORK

International Symposium Measuring and Reporting Intellectual Capital: Experiences, Issues and Prospects. Amsterdam.

Neely, A., Mills, J., Gregory, M., \& Richards, H. (1996). Performance measurement system design: should p process-based approaches be adopted?. International Journal of Production Economics, 46/47, 423431.

Pablos, P. O. (2002). Relevant Experiences in Measuring and Reporting Intellectual Capital in European Pioneering Firms. In Bontis, N., (Eds), World Congres on Intellectual Capital Readings (pp. 157-201). MINT Research Centre, McMaster University, Butterworth-Heinemann.

Pulic, A. (2000). MVA and VAIC analysis of randomly selected companies from FTSE 250. Retrived from www.vaic-on.net.

Pulic, A. (2002). National IC-efficiency report of Croatian economy. Retrived from www.vaic-on.net

Roberts, H. J. E. (1998), Management Accounting and Control Systems in the Knowledge-intensive Firm. Paper presented at the 21st Annual Congress of the European Accounting Association, Antwerp. Belgium

Roberts, H. J. E. (1999). The Control of Intangibles in the Knowledge-intensive Firm. Paper presented at the 22nd Annual Congress of the European Accounting Association. Bordeaux, France.

Roos, G., \& Roos, J. (1997). Measuring your company's intellectual performance. Long Range Planning, 30(3), 413-426.

Ross, G. (2005). Intellectual capital and strategy: a primer for today's manager. In Handbook of business strategy (pp. 123-132). Emerald Group Publishing Limited.

Rucci, A. J., Kirn, S. P., \& Quinn, R. T. (1998). The Employee-Customer-Profit Chain at Sears. Harvard Business Review, January-February, 1998.

Securities and Exchange Commission - SEC. (2000). Regulation FD: Selective Disclosure and Insider Trading, SEC. Washington, DC.

Shiu, H. J. (2006a). Application of the VAIC method to measures of corporate performance: a quantile regression approach. Journal of American Academy of Business, 8(2), 156-160.

Shiu, H. J. (2006b). The application of the value-added intellectual coefficient to measure corporate performance: evidence from technological firms. International Journal of Management, 23(2), 356-365. 
Biserka Komnenić, Jovan Njegić | 159

Starovic, D., \& Marr, B. (2010). Understanding corporate value: managing and reporting intellectual capital. Chartered Institute of Management Accountants.

Stewart, T. A. (1997). Intellectual Capital: The New Wealth of Organizations. New York: Doubleday/Currency.

Stewart, T. A (1999). The Wealth of Knowledge. London: Nicholas Brealey Publishing.

Sveiby, K. E. (2010). Methods for Measuring Intangible Assets. Retrived from

https://www.sveiby.com/files/pdf/intangiblemethods.pdf

Sveiby, K. E. (1997). The intangible asset monitor. Journal of Human Resource Costing and Accounting, 2(1), 73-97.

Taylor, S. (1999). Full disclosure 1998. Shelley Taylor, London, United Kingdom.

Work-Life 2000. (1998). The value of investing in the workforce. Sweden: National Working Life.

Yeung, M. C. H., \& Ennew, C. T. (2001). Measuring the impact of customer satisfaction on profitability: a sectoral analysis. Journal of Targeting, Measurement and Analysis for Marketing, 10(2), 106-116.

Delivered: 21.10.2019. Accepted: 27.12.2019. 